Received 1 Jan 2020; accepted 2 April 2020.

Available online 30 April 2020

\title{
Enhancing Sustainability of Historic Contexts Through Infill Landscape Projects Infill development as a catalyst for Rehabilitation
}

\author{
Zeinab Feisal \\ Associate Professor of Architecture - Benha Faculty of Engineering - Benha University \\ Zeinab_feisal@hotmail.com
}

\begin{abstract}
Development in historic areas is a very sensitive issue because of the importance of these areas and their multiple values of historical, cultural and economic. Development should aim to emphasize and maximize the value of this context and to make possible contributions to address weaknesses. The aim of this research is to investigate the extent to which the role of added development can be maximized in heritage contexts for sustainability. The study hypothesis is discussing the possibility of enhancing the sustainability of historic contexts through an integral infill landscape project based on the potentials of these projects.

A questionnaire was conducted with architects and planners to determine the expected role of this type of development and how much contribution it should role. Case studies were selected to assess the extent to which the infill development in heritage domains could achieve sustainability. An analytical comparative study was done based on qualitative methods by studying the case studies of infill landscape projects that were added and positively affected the historic context.

The research then proceeds with a set of conclusions and recommendations that can be applied when adding development in historic contexts.
\end{abstract}

Keywords: Infill Development, Sustainability, Historic, Context, Landscape projects

\section{INTRODUCTION}

While there looks to be an apparent conflict between urban conservation and development, it can sometimes be recognized as couple sides of a coin (Aroz, 2013), especially when development is used to contribute to the preservation of heritage and to emphasize the character of place. In some cases, urban development threatens the continuity of heritage. UNESCO's recommendations in 2011 have tended to ensure that development in these domains has to be comprehensive and integrated.

Cities have got a vital position in economic, cultural, social and environmental policymaking and there is inclusive and transdisciplinary attention in urban cultures (Soja, 2011). The present era can be called the urban era. Where many parts of the world have been rapidly urbanized since the second half of the eighteenth century, creating expectations that the urban environment will gain an important place in the future. The desire to rebuild entire urban centers to become platforms for the present urban era has grown, as the cities in the 1980s became the focus of political and economic transformations of the new global period (Sassen, 2011). As a result, Management of cities has become more complex, and attention has grown to the increasing urbanization of the world. This has been reflected on cities with the emergence of many attempts to reach sustainable, smart or resilient cities (De Jong et al., 2015). 


\section{INFILL DEVELOPMENT}

Infill development refers to the new development that occupies empty or vacant spaces or that is removed from dilapidated buildings or inappropriate uses. This development takes place in the urban areas of the societies where the infrastructure already exists. It gives the opportunity to fill gaps in current societies and play a crucial role in revitalizing society and preserving land.

Infill Development is the solution to enhance the character, vitality and functionality of the Old Town. This paper discusses the comprehensive development to address evolving impacts, focusing on Landscape projects added as infill development in historical areas and making this development as an approach for sustainability.

\section{INFILL LANDSCAPE PROJECTS - CHALLENGES AND OPPORTUNITIES}

Although there are many opportunities for successful Landscape projects, there are several Challenges facing it, such as physical Challenges, social Challenges, Regulatory Challenges, Economic Challenges, infrastructure Challenges and the development scale (Faris [1]). Landscape infill projects in historic context may offer many opportunities such as:

- The provision of green areas, which most of the historic districts suffer from a lack of green spaces.

- Encourage social interaction by providing places for gathering and meeting and a range of recreational activities, as well as a sense of safety and belonging.

- Emphasize the character of place through a design that integrates with the visual image of the context.

- Improve the environmental performance of the historic area and reduce the level of pollution that affects the historic buildings and their sustainability.

- Maximize the utilization of existing public utilities. Increase the efficiency of public transport, encourage walkability, take advantage of existing infrastructure, and reduce the need for a new cost.

- Create a new attraction for the context and increase the livability of the historical area and restore its value.

\section{INFILL DEVELOPMENT AND SUSTAINABILITY OF HISTORIC CONTEXT}

In the broad context, Sustainable urbanism minimizes the negative impacts of urban development by involving a combination of values: aesthetic, environmental, social, political, and moral.

Environmental conditions in historical contexts are very sensitive due to their impact on heritage such as high pollution rates and their effects on the outer envelope of the historic buildings. Development in historical areas may represent an opportunity to improve environmental conditions through adding green spaces if there is enough space or using of modern technologies such as green roofs, green facades and other technologies that help improve the environmental performance of the building and its context.

The role of infill development in achieving the economic sustainability of the historical context through the integration of function of the projects added within the context to provide activities that integrate and reply to the needs of the community and does not negatively affect the context. The choice of the added project's functions may 
contribute to creating attractions for the region and provide new opportunities for work and bring life to the place.

Sociocultural sustainability is greatly influenced by infill development in the historical context, where these contexts represent the memory of the community and successful infill development that emphasizes the identity of the place. Development may contribute to rooting a sense of security and belonging to individuals and possibly creating activities that help increase social interaction.

\section{CASE STUDIES OF INFILL LANDSCAPE PROJECTS IN HISTORIC CONTEXT}

Case studies were selected considering that:

- Location of the park related to a historic context

- The park is established as a landscape project not attached to a building

- Case studies are public parks not specialized parks (zoo, botanic, ....)

- The park has to be accessible for community

- Availability of information.

There are several cities around the world uses the infill landscape approach to add green spaces in their historic districts:

\subsection{Pulaski Park, Northampton, Massachusetts, USA}

The Pulaski Park project, that won the ASLA Award in 2018, is one of the most prominent projects implemented with the aim of recreating an effective green space in the historic heart of the city. The project was originally a design competition announced in 2008 and postponed until 2012 when the city engineer cooperated with landscape architect for finding a grant fund of 1.85 million \$. Several public meetings were held throughout the year with the aim of giving the landscape architect an opportunity to truly feel the place and how to design a park that reflects the spirit of the place and correspond to its heritage value.

\subsubsection{Location}

The park is located in the historical downtown of Northampton, Massachusetts. It is situated on Main Street between the City Hall and the Academy of Music Theatre. The park occupies an area of 2.5 acres.

Figure (1) Pulaski Park location

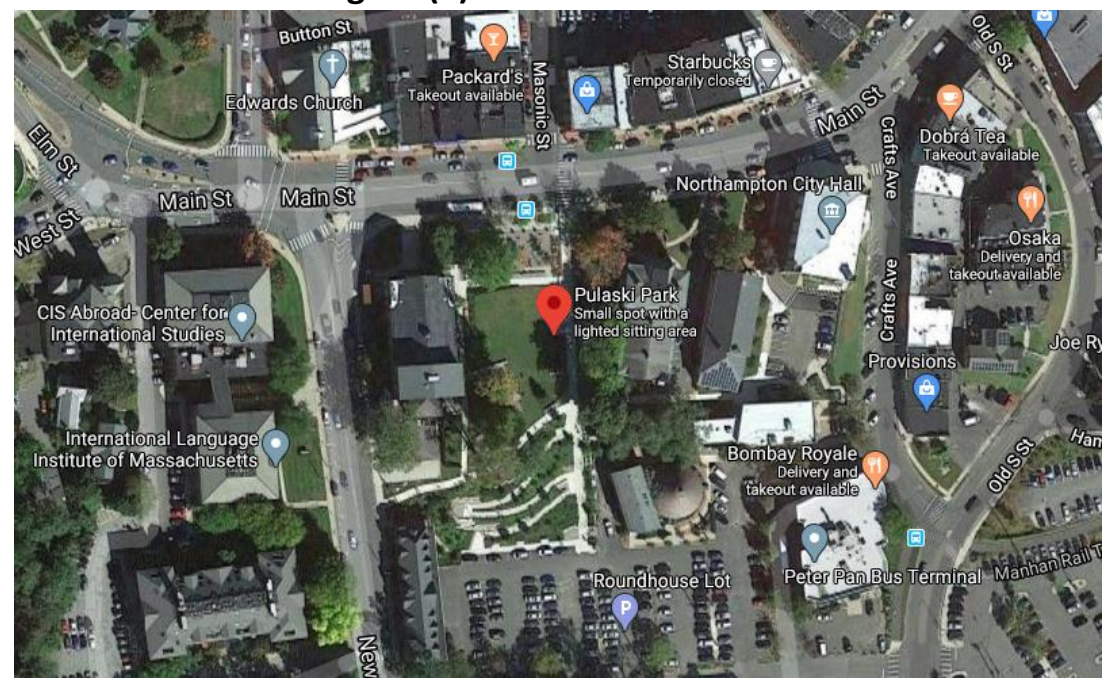

Source: Google maps

\subsubsection{The Design and the context}


The design philosophy has stemmed from the diversity of Northampton city and how the renovated park represents the city's cultural and ecological history (Gibso, 2018).

Design inspiration comes from the history of the original park that was linked with the ecological system of the Mill historic river (ASLA, 2018). This river was running throw the city center and near the original park. The design of the park focused on reviving the ecological link with the river by planting original plants and highlighting the environmental role of the park.

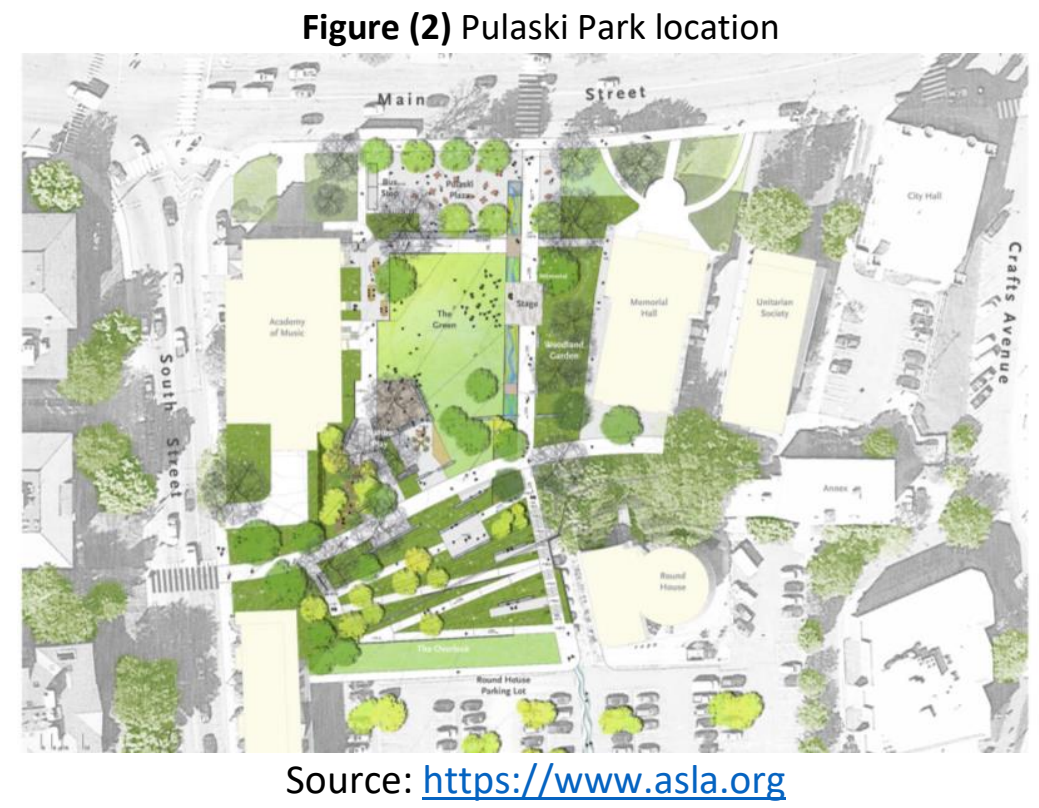

The park was last renovated in the 1970s, the renovation process was depending on paving most of the site and minimized green spaces. The design has neglected creation of attractions for community that transformed the park to a poor condition and Degradation. The goal of the new design was to bring life back to the place by returning the community to the place and creating diverse attractions for the public.

Figure (3) Pulaski Park before and after the project
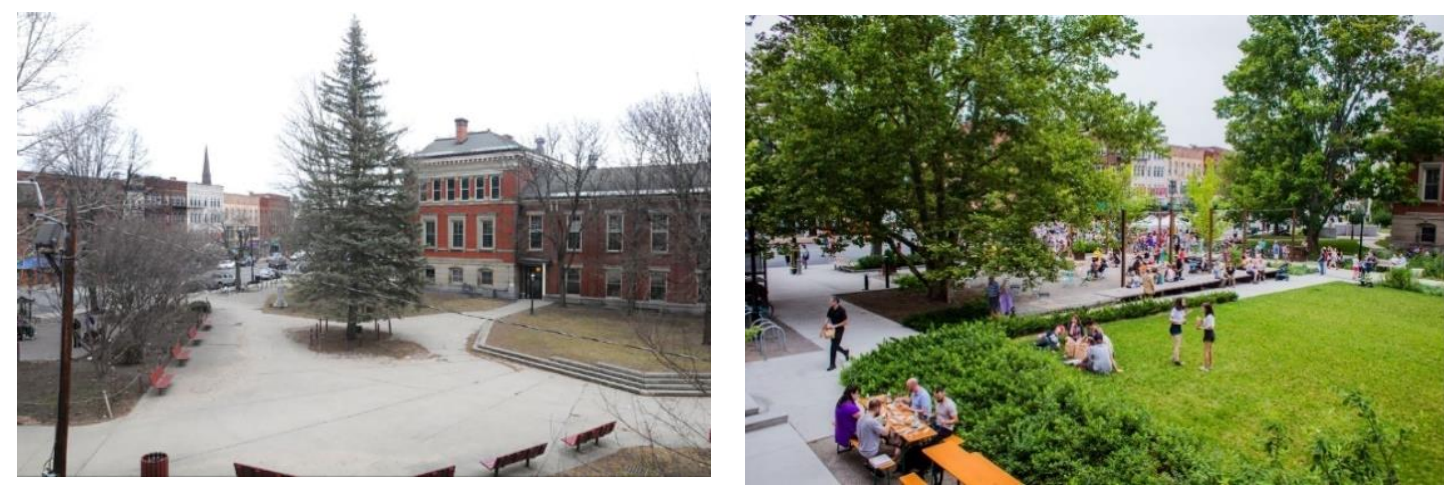

Source: www.northamptonma.gov

The renovated park designed in diverse zones that offer several functions for the community; the Plaza, the green, woodland garden and nature play area. It consists of shade trees, walkways, benches, a playground, and a small stage (Pulaski, 2016). 
The infill park project in the downtown urban district has gone far beyond the original brief. It has generated a renewed sense of community by extending its presence into the surrounding streets.

\subsubsection{The park effect on sustainability of the context}

\section{- Environmental sustainability}

Preserving the environment: The park was designed on the location of a former park, and the design tried to inspire by the history of the original park. Reviving the spirit of Mill river that was passing near the park by choosing the type of trees that were growing close to the river.

Improve the environmental impact: The new design has focused on increasing the area of greens in the park to be a breath for the downtown area.

\section{Conserving resources:}

The new design has an environmentally friendly feature added to the park that was a stormwater garden consisting of plants that absorb rainwater and naturally treat it before being carried into the storm drainage system.

Using local materials in design; such as the playing area where stone slabs and logs were used instead of usual play equipment. By reclaimed granite and slabs of Goshen stone from a quarry which located just 20 miles away, their ideas were realized.

\section{Increasing environmental awareness:}

The stormwater garden relieves the pressure of the conventional system and heightens the public awareness of green infrastructure opportunities in the urban environment.

\section{- Socio-cultural sustainability}

The character of place was emphasized in the design of the park, as the design diversity was inspired by the context's history, attitude, culture and values. Local materials, industrial detailing and a familiar plant palette resonate with Northampton's cultural and ecological heritage.

\section{Raising the cultural awareness:}

The park provides a range of cultural activities in Pulaski Plaza which forms a civic space of permeable paving for engaging the vibrant activities of downtown (street performance, social activism and community festivals). At the park's west edge, a stage bridges over the stormwater garden and extends into the woods garden for regular events.

\section{Give opportunity for social interaction}

The park provides an opportunity for social interaction, as a community green, central open space for familiar gathering, play and events. An iconic tree was placed at the southern edge with ample gathering space around it for festivities.

The park attracts many children for playing in the natural play area and enjoying the green space.

\section{Community participation}

- The Park represents a small-scale version of the community's vision and their needs for green space, plaza, play area and garden.

- The community participated in the proposed design phase of the project that series of public meetings during the preparation stage for the design, led by the Landscape Architect, gave the project a real sense of place. 
- The play area was designed with participation from local children in public forums.

The effect of the park on the visual image: The renovated park enhanced the visual image of the context.

\section{- Economic sustainability}

Increase land value: The renovation of the park has increased the land value of land lots overlooking the garden.

\section{Self-sufficiency:}

- Using Local materials in the park zones reduces the cost of maintenance.

- The design considered the creation of sources of income for the park by using the park fence to set up a group of stores to display and sell artistic products and handicrafts.

- There is a cafeteria, but it is currently closed, and it was a source of income for the garden.

\subsection{Damascus Environmental Gardens}

This project has won the competition that was held by the Swiss Embassy in Syria. It is the first ecological garden in Syria near The Damascus fortress.

\subsubsection{Location}

The project is located in the heart of old "Damascus", next to the Old City walls and the Barada River. In the past, two river branches were passing through the site and the site was full of orchards. As a result of the urban development, the area turned into a dump site for waste, then it turned into a garage for rubbish cars and street vendors, which transformed the site then into an uncivilized appearance. After that, the site was converted from a dump site and a source of pollution to an environmental garden.

The Syrian Environment Association takes over the process of establishing the garden in 2003 in cooperation with the Swiss embassy that funded a good part of the project, with an area of 1700 square meters.

Figure (4) The Environmental garden location

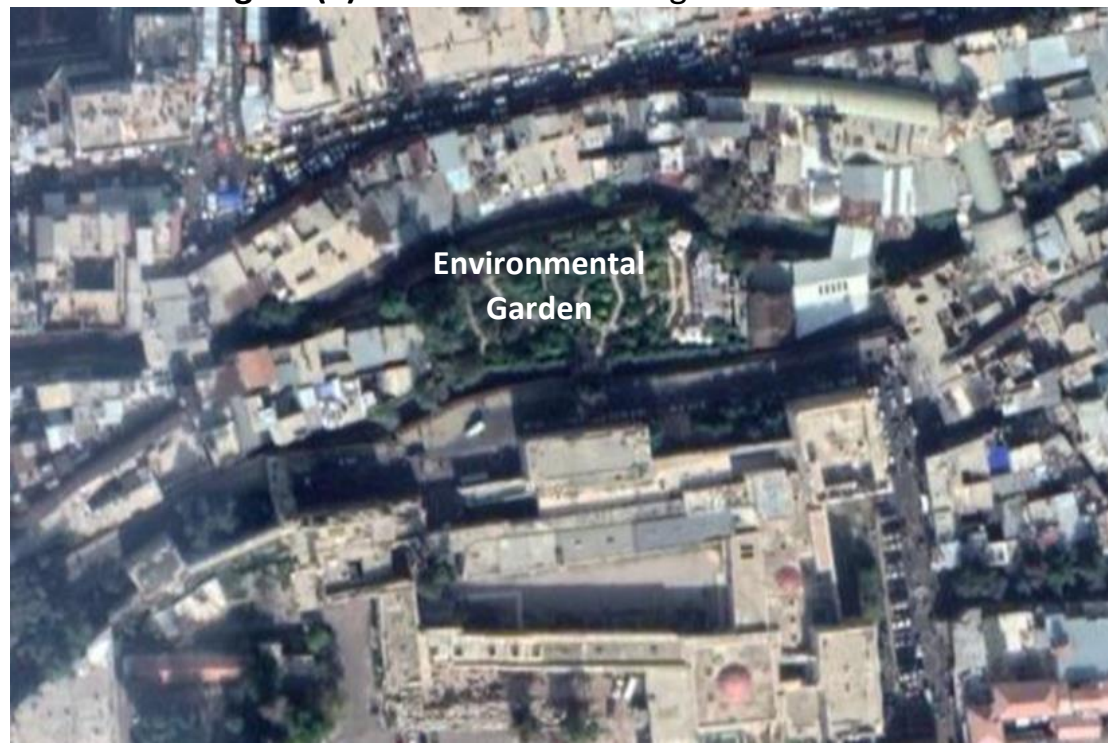

Source: google maps 


\subsubsection{The Design and the context}

It is the first ecological park created in "Syria", specifically in the heart of old "Damascus". The construction materials were chosen to conform to this historic context. The stone walls were built instead of dirt walls that were around the two branches of the river passing through the garden site in the past. In order to match the wall of the old city and to be more durable.

Figure (5) Using stone and wood in the garden
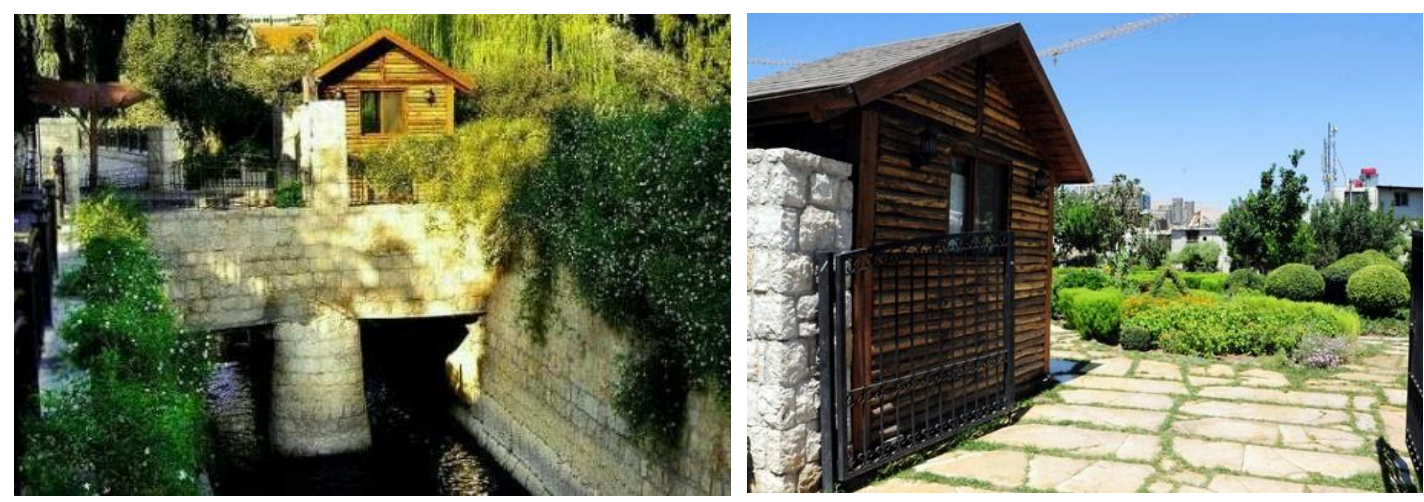

Source: http://esyria.sy/

The design of the park consists of thirty islands with stunning views. Each of them contains a special type of plants, including: "Shadow Plants Island, Rocky Plants Island, Old Ornamental Island, Forest Island, Water Island, Ghouta Crops Island, Fruit Tree Island," and many others. This garden includes about three hundred different plant species, representing the most important and famous plant species, equivalent to ten percent of the plants present in the whole of "Syria". As the design attempted to contain most of the famous plants in most of the Syrian regions. It also included among its plants the Shami House, Ghouta, "Damascus", the Barada Valley, and the mountains surrounding it. So, it was called the Levantine Garden.

Figure (6) Upper view for the garden showing the design

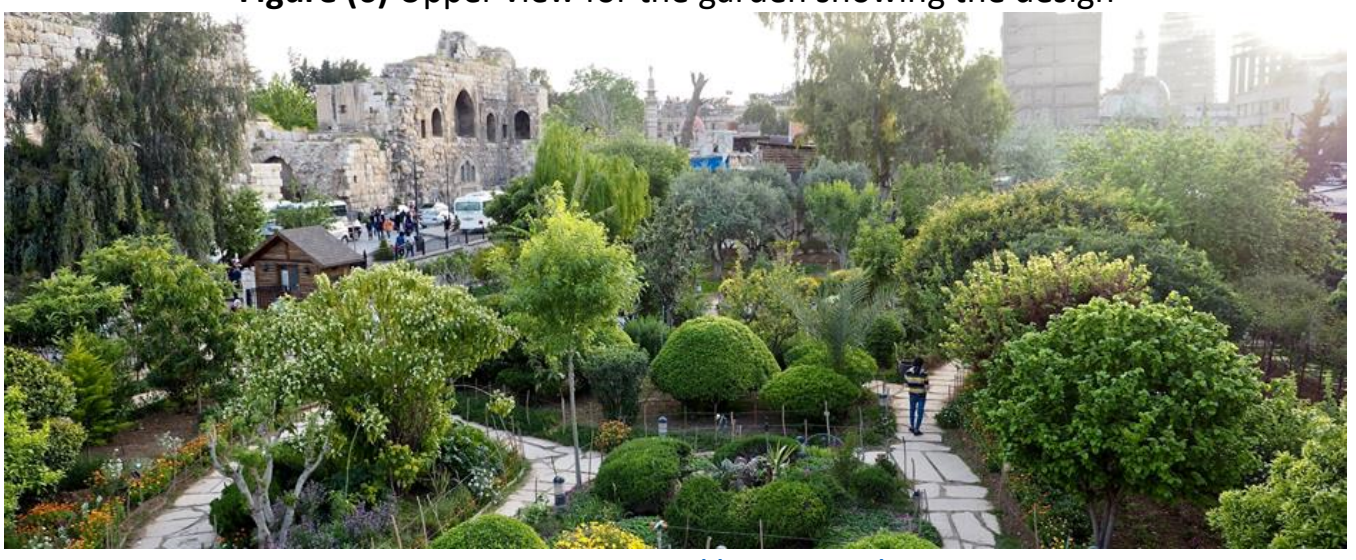

Source: http://esyria.sy/

\section{Architectural character}

The design was influenced by the context and vocabulary of Islamic architecture, and this was demonstrated by covering the facades of the buildings using the Hashemite stone and woody openings inspired by Mashrabiya, and some elements of Islamic architecture such as Shokhsikha. 


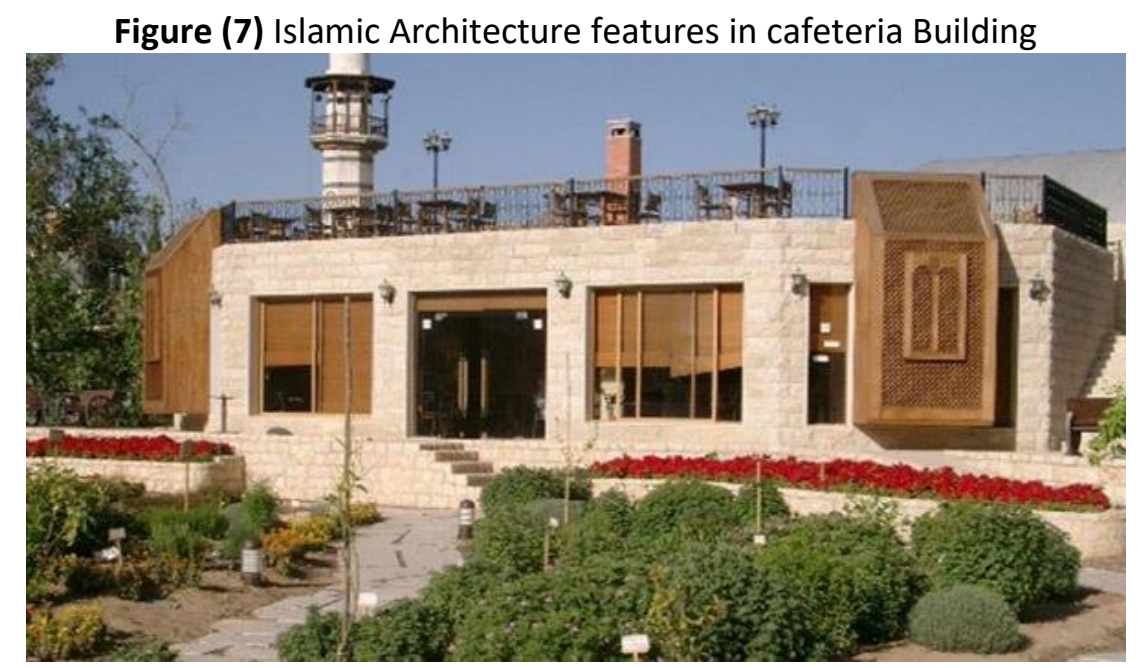

Source: http://esyria.sy/

\subsubsection{The park effect on sustainability of the context:}

\section{- Environmental sustainability}

The project site was converted from a dump site and a source of pollution to an environmental garden.

The park has been established to achieve the following environmental goals:

- Reviving the bond between man and his renewable natural resources, including water, plants and soil.

- Raising awareness, especially among new generations, of the importance of caring for and protecting the environment.

- Link education to the environment.

- Spreading knowledge of the biological diversity that dominates Damascus and its Basin.

\section{- Socio-cultural sustainability}

The character of Damascus was emphasized in the design of the park, as it includes about three hundred different plant species, representing the most important and famous plant species. As the design attempted to contain most of the famous plants in Damascus.

Raising the cultural awareness: The park hosts a range of cultural activities such as poetry gatherings and musical evenings.

\section{Give opportunity for social interaction}

The park encourages social interaction as it attracts large numbers of diverse visitors, including: the Syrian Association for Documentation and Discovery, and many schools that bring their students to show them the importance of the environment, And university students as well, such as students of the College of Science and Agriculture who visit the park to see rare plants. Architecture students visit the garden to learn from the landscape design. In addition to the interest of tourists in the park. The effect of the park on the visual image: The park improved the visual image of the context. 


\section{- Economic sustainability}

Create job opportunities: The park added job opportunities in various specialties for working in the project.

\section{Self-sufficiency:}

- Local materials were used in some park areas, in addition to using of built-in furniture in some elements, which reduces the cost of maintenance.

- The design considered the creation of sources of income for the park by establishing a cafeteria that offers a source of income for the garden. It was agreed between the governorate of Damascus and the Swiss embassy that the cafeteria gain is a legitimate and public income, which the civil society can benefit from in caring for and caring for the garden, from periodic and monthly maintenance work, and any projects aimed at protecting the environment in Syria.

\subsection{Cultural Children's Park, Cairo, Egypt}

The Cultural Children's Garden Project, which won the Aga Khan Award for Architecture in 1992, is one of the most prominent urban projects implemented in the Arab world at this time. The project was presented as a competition by the Ministry of Culture at the end of the 1980s to design a cultural and educational park for children, which includes galleries, a museum, a theater, a library and a nursery.

\subsubsection{Location}

The project is located in Al-Sayeda Zeinab historically significant district in the center of medieval Cairo (Cairo Governorate, 2010). It occupies a historic site for a park dating back to the Mamluk-era. It was known as El Hod El-Marsoud. This urban project occupies an area of 12,000 square meters.

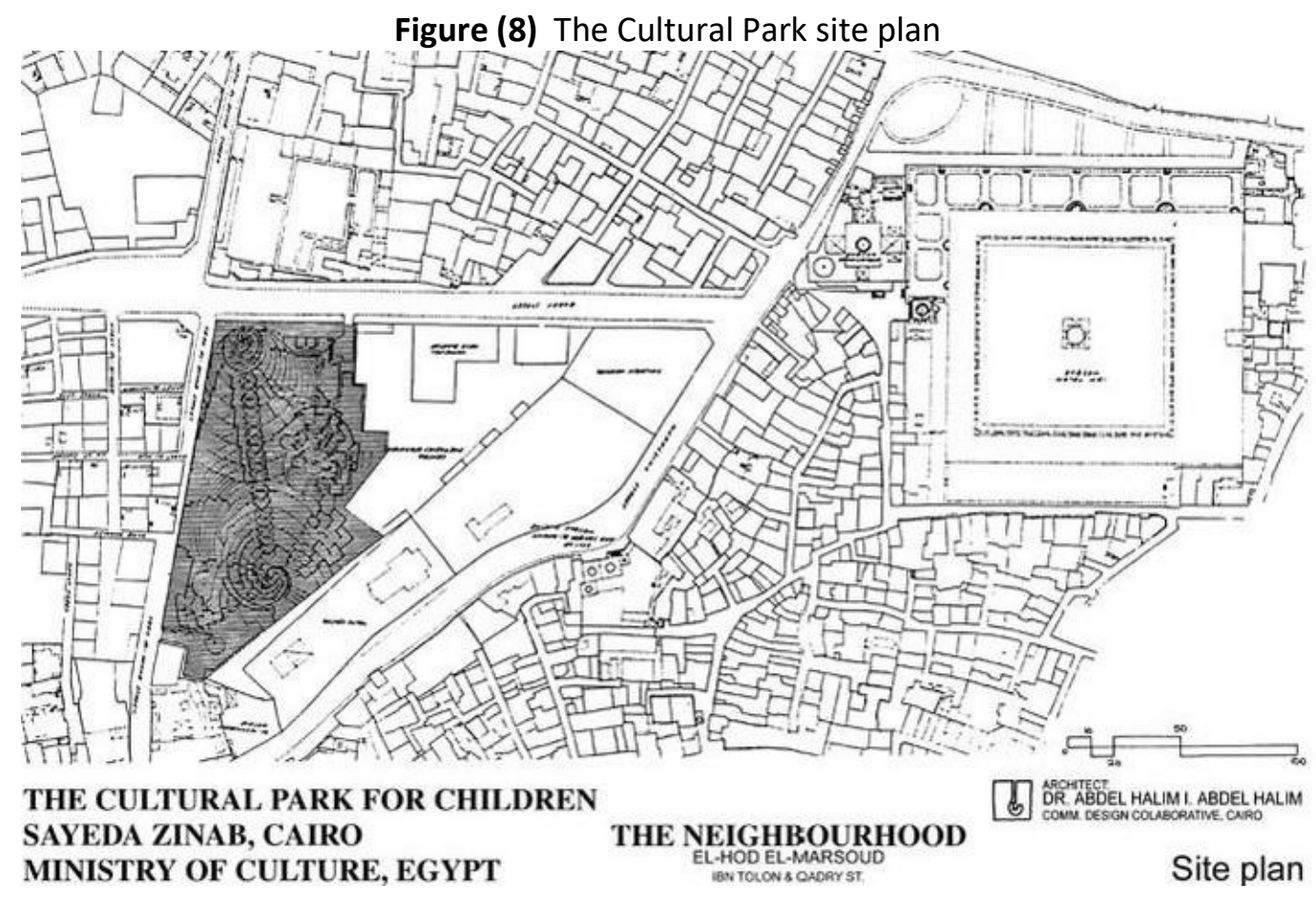

Source: Dr. Abdel Halim Ibrahim 


\subsubsection{The Design and the context}

The philosophy of design may have stemmed from a series of questions about the various dialectical relations between the elements of the project and the location of the park, as well as between the history of the site and its surrounding heritage.

Design inspiration comes from the surrounding location which provided the raw material for the design. One of the views close to the site is Ibn Tulun Mosque, which is characterized by its minaret (Malawiya) which mimics (Samarra Malawiya). This form resembles the sultry tree that rooted in the depth of history.

Preserving the group of palm trees existing on the site was one of the priorities of the design philosophy and surrounding them by spiral designs.

The design geometry was based on the spiral shape which inspired by the minaret of Ibn Tulun Mosque and palm trees were used as engineering coordinates of the snail. The level of the traffic pathways has been changed upward, giving a renewed visual image of the walker in the park.

Figure (9) The Cultural Park layout

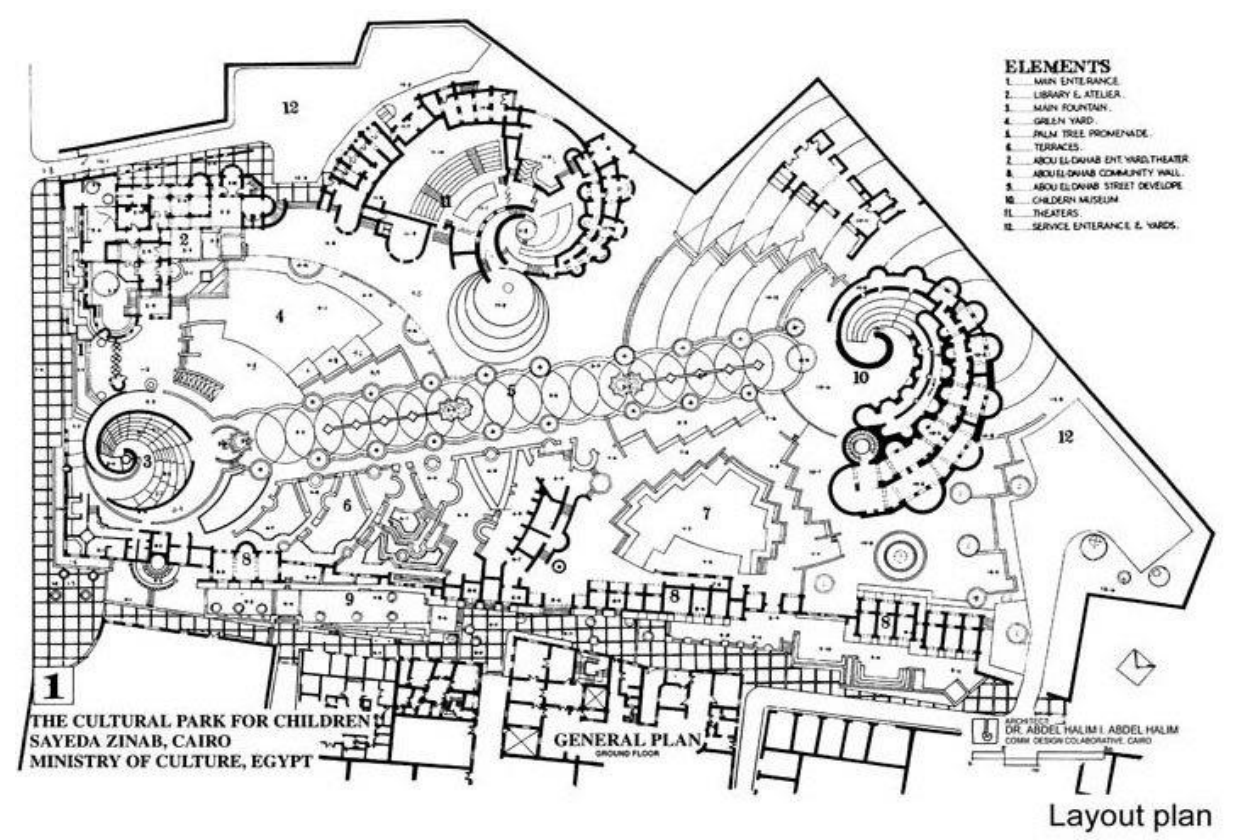

Source: Akbar Jamil, 1992

Transparency and visual interaction: The design considered the visual communication with the surroundings through the design of the park fence, which is characterized by its low height and the use of arched openings that allow the neighbors to enjoy the nature of the project.

Figure (10) The Cultural Park Cross section

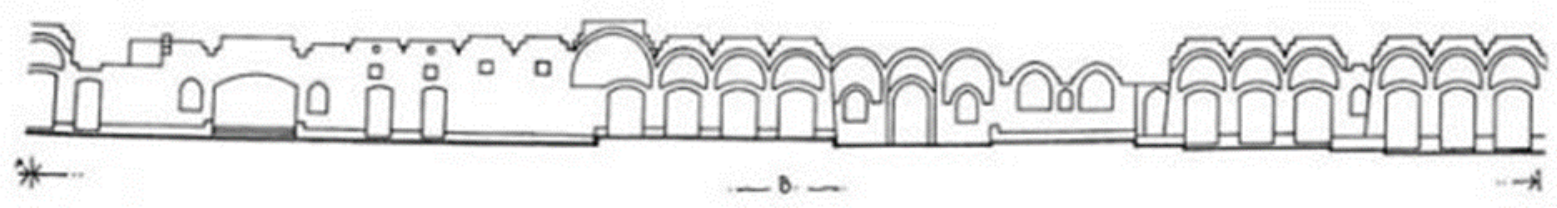

Source: Akbar Jamil, 1992 


\section{Architectural character}

The designer tried to take advantage of the context and essence of the Islamic architecture in an indirect and more abstract way. The design problem was how to design the buildings to ensure the connection between contemporary intellectual movement and at the same time in harmony with the Islamic cultural context. This has been shown through the cladding of the facades of the buildings with the use of the Hashemite stone and the wooden openings inspired by the Mashrabiyah, and the use of Islamic Shokhshikha in an innovative manner in some buildings of the project.

Figure (11) Architecture character of the Cultural Park

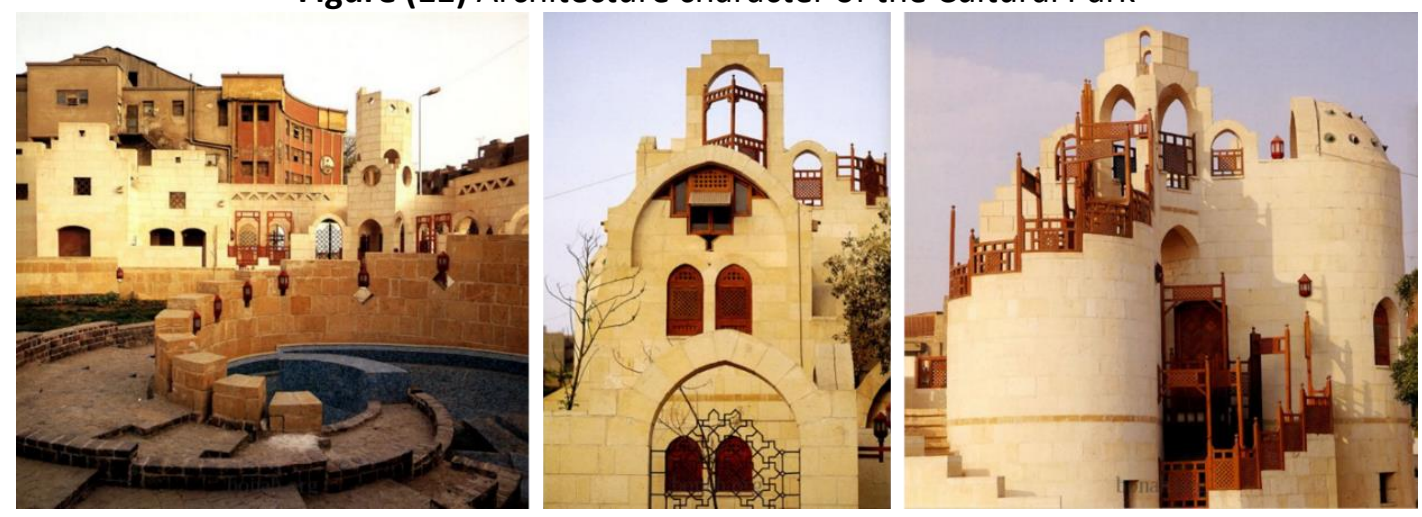

Source: Alam El Benaa

The park offers several functions for the community, including an outdoor cafe, street fountain, small shops, seats, a community room and library, a prayer space, a large festival plaza, a clinic and other community services. The infill park project in the congested urban fabric has gone far beyond the original brief. It has generated a renewed sense of community by extending its presence into the surrounding streets.

\subsubsection{The park effect on sustainability of the context}

\section{- Environmental sustainability}

Preserving the environment: The park was built on the place of a former garden (Elhod Elmarsod), and some of the palm trees that were existing on the site were preserved.

Improve the environmental impact: Majority of the garden area is hardscape and buildings, and the green surface is limited in relation to the area of the garden, where we find that only $12 \%$ are shaded with trees (about 35 trees only in the park) and this has resulted in reducing the environmental impact of the garden in alleviating the air temperature, reducing wind speed and reducing pollution rates from the surrounding areas.

\section{Conserving resources}

- Irrigation is carried out using hoses, in addition to using drinking water to irrigate the garden, which leads to water waste.

- Kinds of plants in the garden require a lot of irrigation water and don't save in water consumption except for some limited cactuses.

- Garden lighting units are energy- wasteful and manually controlled. 
Increased environmental awareness: Some workshops are held in the park to teach children some artistic activities by recycling materials, and show some examples of them in the garden to increase children's environmental awareness.

\section{- Socio-cultural sustainability}

The character of place was emphasized in the design of the park, as the design geometry was inspired by Ibn Tulun Mosque in addition to some Mamluk and Ottoman buildings located in the context.

Raising the cultural awareness: The park provides a range of cultural services such as the library, theater and other cultural activities. These activities develop the children characters and skills and help them to express themselves.

As the garden is for children, most activities were directed to children, except in Ramadan, during which some concerts and activities are held for all family members.

\section{Give opportunity for social interaction:}

The park provides an opportunity for social interaction, especially among children, as the park allows children or parents to enter with their children. The garden helped through activities - to strength friendship between young dwellers from surrounding areas as they meet to socialize after school or at the time of the summer vacation.

\section{Community participation}

- The surrounding community participated in the proposed design phase of the project and some proposals were implemented, such as placing the library in the place of the child care center.

- Children's artwork is displayed in the park

- Children can participate in preparing for the celebrations

The effect of the park on the visual image: The park improved the visual image of the context.

\section{- Economic sustainability}

Create job opportunities: The park provided job opportunities, with about 65 employees working in the park with various specialties.

\section{Increase land value}

- The prices of the units overlooking the garden increased by $40 \%$ over the nonoverlooking ones.

- The Owners of shops overlooking the park believe that few working hours reduces movement in the street, and hence the demand for shops.

\section{Self-sufficiency}

- Local materials were used in some park areas, in addition to using of built-in furniture in some elements, which reduces the cost of maintenance.

- The design considered the creation of sources of income for the park by using the park fence to set up a group of stores to display and sell artistic products and handicrafts.

- There is a cafeteria, but it is currently closed, and it was a source of income for the garden.

- Currently the park totaly depends on the budget set from Ministry of Culture. 


\section{Comparative analysis of case studies}

In this part, the research concludes the effect of the selected infill landscape projects on achieving sustainability to the context.

\begin{tabular}{|c|c|c|c|c|}
\hline & $\begin{array}{l}\text { Pulaski Park, } \\
\text { Northampton }\end{array}$ & $\begin{array}{c}\text { Damascus } \\
\text { Environmental } \\
\text { Gardens }\end{array}$ & $\begin{array}{c}\text { Cultural } \\
\text { Children's } \\
\text { Park, Cairo }\end{array}$ \\
\hline \multirow{6}{*}{ 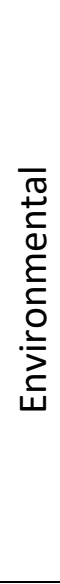 } & Better air quality & & & \\
\hline & Add green spaces & & & \\
\hline & Improve Biodiversity & & & $\square$ \\
\hline & Reduce pollution & & & $\mathbf{E}$ \\
\hline & Conserving resources & & 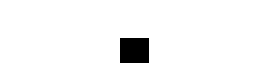 & $\square$ \\
\hline & $\begin{array}{l}\text { Increase environmental } \\
\text { awareness }\end{array}$ & & & \\
\hline \multirow{6}{*}{ 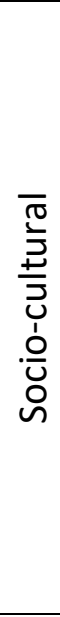 } & $\begin{array}{l}\text { Enhances the character } \\
\text { of place }\end{array}$ & & D & \\
\hline & $\begin{array}{l}\text { Raising the cultural } \\
\text { awareness: }\end{array}$ & & & E \\
\hline & $\begin{array}{l}\text { Give opportunity for } \\
\text { social interaction }\end{array}$ & & & \\
\hline & Community participation & & $\mathbf{a}$ & \\
\hline & $\begin{array}{l}\text { Enrich the context visual } \\
\text { image }\end{array}$ & & & \\
\hline & $\begin{array}{l}\text { Inject new life into } \\
\text { community }\end{array}$ & & & \\
\hline \multirow{5}{*}{ 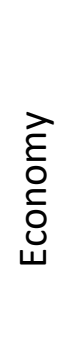 } & Offer job opportunities & & $\mathbf{\square}$ & $\mathbf{\square}$ \\
\hline & Increase land value & & $\square$ & $\square$ \\
\hline & Revival of context & & $\mathbf{\square}$ & $\mathbf{\square}$ \\
\hline & Minimizing running cost & & $\square$ & $\square$ \\
\hline & Self-sufficiency & & a & $\square$ \\
\hline
\end{tabular}

Source: researcher ( $\square$ Effective, $\square$ Partially effective, $\square$ Ineffective )

It is clear from the previous table, the ability of case studies to influence the historical context and contribute to achieving sustainability, whether at the environmental, social or economic levels. 


\section{Conclusions and Recommendations}

Different infill development projects were carried out in historic contexts from different locations around the world. The projects realized the value of the context and affected by its features with different approaches.

The research focused on infill landscape projects and their effect on the historic context by selecting three case studies. The analysis of cases was carried out according to the aspects of sustainable development, followed by a comparative analysis between the cases that concluded that; the infill landscape can support the sustainability of the historic context; preserving its cultural and historical identity, improve the environmental conditions, adding green spaces, give opportunity for social interaction, enrich the visual image of the context, inject new life into community and improve the economic conditions.
Figure (12) Experiences analysis conclusion

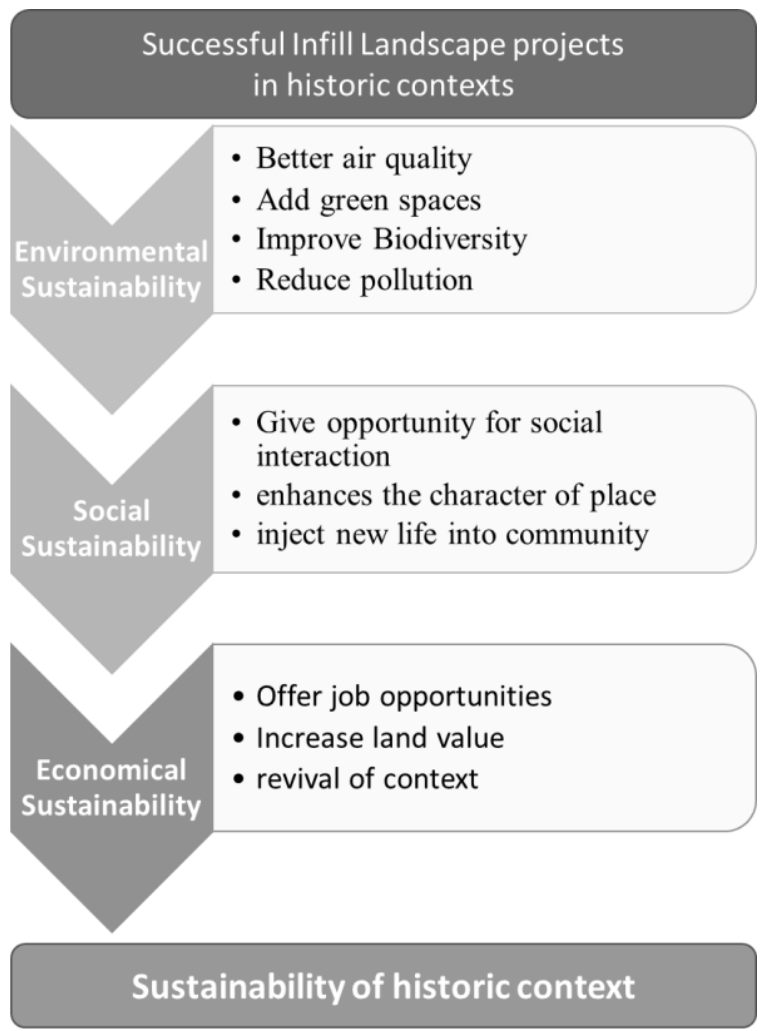

Source: researcher

The research approach is considered one of the solutions to add green spaces in historic contexts, which in turn affects sustainability of these areas.

The research recommends application of infill land scape approach in historic Cairo, especially it suffers from a severe shortage of green spaces and it includes many vacuum lands or degraded buildings proposed to be removed and replaced by new buildings or projects. These lands represent the possibility of adding infill landscape projects like parks or gardens.

There are different examples of proposed infill development projects in historic contexts such as Cairo aqueduct rehabilitation project and rehabilitation of Qasabet Radwan (Al-Khiyamia).

Figure (13). Shots from proposed development projects
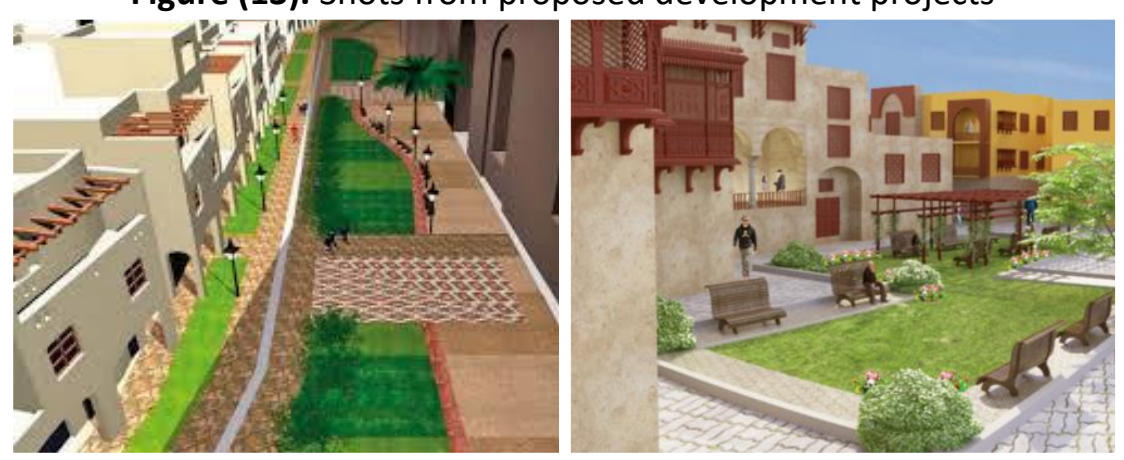

Source: https://www.youm7.com 
From analyzing previous experiences, there is a set of points that must be considered to maximize the positive impact and reduce the negative impact of the project:

- The Design of the added park should emphasize the character of place, be inspired and linked with the context's history, attitude, culture and values.

- It is preferable that the park includes various activities and functions in order to attract different groups of community and provide them with services.

- The landscaping process should be inspired by the environmental conditions of the site: the type of trees that are compatible with the place and does not require special care, Using local materials in the park design.

- The proposed design of the park may include one of the applications of green infrastructure, which may have a great impact in spreading environmental awareness among the members of society and heightens the public awareness of green infrastructure opportunities in the urban environment.

- The park cultural activities are very important to raise the cultural awareness of the community, such as festivals, street performance, celebrations, competitions and exhibitions.

- One of the most important factors for the success of these projects is community participation in any stage of the project.

- The design should take into consideration the creation of sources of income for the park to cover the park maintenance cost.

\section{References}

- Araoz, G. (2013) 'Conservation Philosophy and Its Development: Changing Understandings of Authenticity and Significance', Heritage \& Society 6(2): 144-54

- Abdullah WMZ, (2008). Appropriate Urban Public Open Space, Univ. Teknologi Ma-laysia (UTM), Johor Bahru. Unpublished Ph.D Thesis.

- VEldPAUS L., RODERS A. (2017) "HISTORIC URBAN LANDSCAPE APPROACH AS A TOOL FOR SUSTAINABLE URBAN HERITAGE MANAGEMENT”, University of Jyväskylä and Authors

- Soja, E.W. (2011) 'Beyond Post metropolis', Urban Geography 32(4): 451-69.

- Sassen, S. (2011) 'When Cities Become Strategic', Architectural Design 81(3): 124-7

- De Jong, M. et al. (2015) 'Sustainable-smart-resilient-low Carbon-eco-knowledge Cities; Making Sense of a Multitude of Concepts Promoting Sustainable Urbanization', Journal of Cleaner Production.

- S. S. Aly \& Y. A. Attwa (2013), Infill development as an approach for promoting compactness of urban form, Transactions on Ecology and The Environment,Vol 173

- Salama Ashraf, 2006

- Bentley. I, (1985). Responsive Environments: A Manual for Designers. Architectural Press, Oxford.

- Brolin, B, 1980, Architecture in Context, New York, Van Nostrand Reinhold Company

- CABE , 2001, Building in context New development in historic areas, Wiltshire, English Heritage.

- Çizgen G., (2012), Rethinking The Role of Context and Contextualism in Architecture and Design, (Masters Thesis), Eastern Mediterranean University, Gazimağusa, North Cyprus. 
- El-Habashi, Alaa Elwi (1994). The Building of Auguste Perret in Alexandria: A Case for Preservation of Modern Egyptian Architecture: Historic Preservation Defined. (Mas-ters Thesis). University of Pennsylvania, Philadelphia, PA.

- Eleishe, Azza Mohamed, 1994, Contextualism in architecture: A comparative study of environmental perception. The University of Michigan, 63-75

- Groat, Linda N, (1987), Contextual Compatibility: An issue or Composition, not Replication, Paper Presented at the Association of Collegiate Schools or Architecture, Los Angeles.

- Imam S., (2013), Assessment and review of infill designs' guidelines for Residential ur-ban conservation areas, Int. Journal for Housing Science, Vol.37, No.3, p.137-149.

- Kafafy, N. \& Betawi, Y., n.d. Urban Green Space Benefits and the Pivotal Role of Conservation, Cairo's Case - Egypt. Available at https://eis.hu.edu.jo/deanshipfiles/conf110862020.pdf

- Ostanevics, M. (2017), Infill development in context: Case Study of Riga Circus exten-sion, A thesis Submitted to Umea School of Architecture, Umea

- Rossi A. (1984), "The architecture of the city" The MIT press, Cambridge, Massachu-setts, and London, England.

- Rai, Ruprama (2008), Threats To The Spirit Of The Place Urban Space And Squares, Historic City Core, Kathmandu, Institute for Technology in the Tropics and Sub Trop-ics.

- Semes, Steven W ,(2007), Differentiated' and Compatible': Four Strategies for Addi-tions in Historic Settings, Sense of place: Design guidelines for New construction in Historic districts, Preservation Alliance for Greater Philadelphia.

- Semes, Steven W, 2009, The Future of the Past: A Conservation Ethic for Architecture, Urbanism, and Historic Preservation, W. W. Norton \& Company, 163-178.

- Sotoudeh, H., Abdullah W., (2013), Contextual preferences of experts and residents: issue of replication and differentiation for new infill design in urban historical context, World Applied Sciences Journal 21 (9), 1276-1282

- Sotoudeh, H., Abdullah W., (2012), Affected variables on successful infill design in urban historic context, Arts and Design Studies 3 (9)

- "Pulaski Park | Northampton, MA - Official Website". www.northamptonma.gov. Retrieved 2016-10-05

- Eleanor Gibso, 2018 "America's best new landscape architecture projects revealed", Architecture Article on https://www.caddownloadweb.com/americas-best-newlandscape-architecture-projects-revealed/

- https://www.asla.org/2018awards/455278-Re-Envisioning_Pulaski_Park.html 